Mardiana: Penerapan Pembelajaran IPA Berbasis Konstruktivisme dalam Meningkatkan Sikap Ilmiah pada Siswa Madrasah Ibtidaiyah

\title{
PENERAPAN PEMBELAJARAN IPA BERBASIS KONSTRUKTIVISME DALAM MENINGKATKAN SIKAP ILMIAH PADA SISWA MADRASAH IBTIDAYAH
}

\author{
Mardiana \\ Dosen STIQ Amuntai, Kalimantan Selatan, Indonesia \\ Email:Mardianabiologi12@gmail.com
}

\begin{abstract}
Abstrak
Hakikat sains terdiri atas tiga aspek yaitu sains sebagai produk, proses, dan sikap ilmiah. Dalam pembelajaran IPA masih kurangnya penanaman nilai sikap ilmiah yang berakibat pada peroleh hakikat sains yang tidak utuh dan kurangnya terbentuk sikap ilmiah siswa. Oleh karena itu, proses belajar mengajar harus menggunakan cara dan metode yang sesuai dalam mencapai tujuan pembelalajaran, khususnya pada pembelajaran IPA. Hal tersebut bisa dilakukan dengan pembelajaran IPA berbasis konstruktivisme yang secara langsung dapat membuat siswa secara aktif mengkonstruksi pengetahuan sendiri, sehingga dapat mengembangkan kemampuan berpikir siswa, meningkatkan penguasaan materi pembelajaran dan dapat menumbuhkan sikap ilmiah yang secara tidak langsung akan mempengaruhi sikap siswa dalam memecahkan masalah yang ada di lingkungan sekitar. Penelitian ini merupakan penelitian tindakan kelas (PTK) bertujuan untuk mengetahui peningkatan sikap ilmiah pada siswa kelas V Madrasah Ibtidayah Negeri Sinar Islam. Terdapat peningkatan sebanyak 7,7 \% dari siklus 1 ke siklus2. Sikap ilmiah sangat bermakna dalam interaksi sosial, ilmu pengatahuan dan teknologi. Apabila sikap ilmiah telah terbentuk dalam diri siswa maka akan terwujudlah suri tauladan yang baik bagi peserta didik, baik dalam melaksanakan penyelidikan atau berinteraksi dengan masyarakat. Secara tidak langsung sikap ilmiah dalam proses pembelajaran IPA dapat menyelesaikan masalah-masalah moralitas anak bangsa ini.
\end{abstract}

Kata Kunci : Pembelajaran IPA, Konstruktivisme, Hasil Belajar Kognitif, Sikap Ilmiah

\section{A. Pendahuluan}

Pendidikan merupakan suatu usaha yang dilaksanakan secara sadar dan terencana oleh pemerintah dan masyarakat dalam mengembangkan berbagai kompetensi siswa, baik kognitif, afektif, maupun psikomotor ke arah yang lebih 
Mardiana: Penerapan Pembelajaran IPA Berbasis Konstruktivisme dalam Meningkatkan Sikap Ilmiah pada Siswa Madrasah Ibtidaiyah

sempurna sehingga dapat meningkatkan kualitas pendidikan nasional. ${ }^{1} \mathrm{Hal}$ tersebut tercantum dalam UU No 20 tahun 2003 tentang sistem "pendidikan nasional berfungsi mengembangkan kemampuan dan membentuk watak serta peradaban bangsa yang bermartabat dalam rangka mencerdaskan kehidupan bangsa, yang bertujuan untuk berkembangnya potensi peserta didik agar menjadi manusia yang beriman dan bertaqwa kepada Tuhan Yang Maha Esa, berakhlak mulia, sehat, berilmu, cakap, kreatif, mandiri, dan menjadi warga negara yang demokratis serta bertanggung jawab". ${ }^{2}$

Pembelajaran IPA di Sekolah Dasar merupakan pondasi awal dalam menciptakan siswa-siswa yang memiliki pengetahuan, keterampilan dan sikap ilmiah. Pembelajaran IPA diarahkan dengan cara mencari tahu tentang alam secara sistematis, sehingga IPA bukan hanya merupakan penguasaan kumpulan pengetahuan yang berupa fakta-fakta, konsep-konsep, atau prinsip-prinsip saja, tetapi juga merupakan suatu proses penemuan dan pembentukan sikap ilmiah.

Pembelajaran IPA memiliki hakikat yang dapat diklasifikasikan menjadi tiga bagian yaitu IPA sebagai produk, IPA sebagai Proses, dan IPA sebagai sikap. Dari ketiga kompenen IPA ini, IPA juga sebagai prosedur dan IPA sebagai teknologi. Akan tetapi penambahan ini bersifat pengembangan dari ketiga komponen di atas, yaitu pengembangan prosedur dari proses, sedangkan teknologi dari aplikasi konsep dan prinsip-prinsip IPA sebagai produk. ${ }^{3}$ Sikap dalam pembelajaran IPA yang dimaksud ialah sikap ilmiah, jadi dengan pembelajaran IPA di sekolah dasar diharapkan dapat menumbuhkan sikap ilmiah seperti seorang ilmuwan. Adapun jenis-jenis sikap yang dimaksud adalah

\footnotetext{
${ }^{1}$ Darmiwati. Implementasi Model Pembelajaran Perubahan Konseptual Untuk Meningkatkan Prestasi Belajar. (Banda Aceh: FKIP Unsyiah, 2006), h. 42.

${ }^{2}$ Undang-undang Republik Indonesia No 20 pasal Tentang Sistem Pendidikan Nasional. (Jakarta: CV Multi Persindo, 2013), h. 55.

${ }^{3}$ Chain \& Evan, Sciencing An Involvement Approach to Elementary Science Methods, (Edisi ke III. Korinna: Merrill,1990), h. 7.
}

Jurnal Ilmiah AL-MADRASAH, Vol. 3, No. 1, Juli-Desember 2018 
Mardiana: Penerapan Pembelajaran IPA Berbasis Konstruktivisme dalam Meningkatkan Sikap Ilmiah pada Siswa Madrasah Ibtidaiyah

sikap ingin tahu, percaya diri, jujur, tidak tergesa-gesa dan objektif terhadap fakta. $^{4}$

Hakikat sains adalah landasan untuk berpijak dalam mempelajari IPA. Banyak cara yang telah dilakukan untuk mencapai aspek yang terkandung di dalam hakikat sains, salah satunya yaitu menggunakan pembelajaran berbasis konstruktivisme.Pembelajaran yang mengaplikasikan model pembelajaran aktif yang dapat mengkonstruk pemikiran siswa sendiri sehingga dapat terwujud hakikat sains secara utuh yang dapat membelajarkan siswa untuk berproses (keterampilan proses) dan juga menanamkan sikap ilmiah, misalnya rasa ingin tahu, jujur, bekerja keras, pantang menyerah, dan terbuka.

Secara sederhana teori konstruktivisme itu beranggapan bahwa pengetahuan merupakan konstruksi dari mengetahui sesuatu. Pengetahuan kita bukanlah suatu fakta yang tinggal ditemukan, melainkan suatu perumusan atau formulasi yang dibuat oleh seseorang yang mempelajarinya ${ }^{5}$ Teori Konstruktivisme tidak bertujuan mengerti tentang realitas, tetapi lebih hendak melihat bagaimana suatu proses, dalam hal ini adalah pembelajaran, dari tidak mengetahui menjadi mengetahui sesuatu tersebut. Maka dalam pandangan ini belajar merupakan suatu proses aktif dari peserta didik untuk mengkontruksi makna, pengalaman fisik dan sebagainya. ${ }^{6}$

Berdasarkan pemaparan diatas maka dillakukan penelitian dengan menerapkan pembelajaran IPA berbasis Kontrukstivisme dalam meningkatkan sikap ilmiah siswa. Karena sikap ilmiah sangat bermakna dalam interaksi sosial, ilmu pengatahuan dan teknologi. Apabila sikap ilmiah telah terbentuk dalam

${ }^{4}$ S Hornby,A. Oxford Advanced Learner's Dictionary Of Current English. (NewYork: Oxford University Pres, 2010). h. 12.

${ }^{5}$ Sardiman A. M, Interaksi dan Motivasi Belajar Mengajar, (Jakarta: PT. Raja Grafindo Persada, 2007), h. 37.

${ }^{6}$ Husin dan Bahrul Ilmi, " Strategi Cooverative Learning dalam Perspektif Pendidikan Islam", Al-Madrasah Vol. 3, No. 1 (2018), h.

Jurnal Ilmiah AL-MADRASAH, Vol. 3, No. 1, Juli-Desember 2018 
Mardiana: Penerapan Pembelajaran IPA Berbasis Konstruktivisme dalam Meningkatkan Sikap Ilmiah pada Siswa Madrasah Ibtidaiyah

diri siswa maka akan terwujudlah suri tauladan yang baik bagi peserta didik, baik dalam melaksanakan penyelidikan atau berinteraksi dengan masyarakat. Secara tidak langsung sikap ilmiah dalam proses pembelajaran IPA dapat menyelesaikan masalah-masalah moralitas anak bangsa ini.

\section{B. Metode Penelitian}

Penelitian ini merupakan penelitian tindakan kelas (PTK) yang terdiri dari dua siklus yaitu siklus I dan siklus II. Adapun subyek penelitian adalah siswa kelas V MIN Sinar Islam dengan jumlah siswa sebanyak 35 orang. Analisis data secara deskriptif menggambarkan perbandingan hasil dari siklus I dan siklus II mengenai peningkatan sikap ilmiah siswa.

\section{Kajian Pustaka}

1. Pembelajaran IPA di Madrasah Ibtidayah

Ilmu pengetahuan alam (IPA) merupakan bagian dari ilmu pengetahuan atau sains yang semula berasal dari bahasa Inggris "science", kata science semula berasal dari kata Latin "Scientia" yang berarti "saya tahu". Science terdiri dari social science (ilmu pengetahuan sosial) dan natural science (ilmu pengetahuan alam), akan tetapi dalam perkembangannya science sering diterjemahkan sebagai sains yang berarti Ilmu Pengetahuan Alam (IPA). ${ }^{4}$

Ilmu pengetahuan Alam (IPA) merupakan ilmu yang berhubungan dengan gejala-gejala alam dan kebendaan yang sistematis, tersusun secara teratur, berlaku secaraa umum, berupa kumpulan hasil observasi dan eksperimen. Dengan demikian sains bukan hanya kumpulan tentang atau makhluk hidup, tetapi tentang tata cara kerja, berpikir dan memecahkan masalah.

Adapun pengertian ilmu pengetahuan alam dalam standar kompetensi kurikulum madrasah Ibtidayah/Sederajat, “merupakan cara mencari tahu tentang 
Mardiana: Penerapan Pembelajaran IPA Berbasis Konstruktivisme dalam Meningkatkan Sikap Ilmiah pada Siswa Madrasah Ibtidaiyah

alam secara sistematis untuk menguasai pengetahuan, fakta, konsep, perinsip, proses penemuan dan memiliki sikap ilmiah. ${ }^{7}$

Mata pelajaran Ilmu Pengetahuan Alam di sekolah tingkat dasar bertujuan untuk: 1) Mengembangkan pengetahuan dan pemahaman konsepkonsep Ilmu Pengetahuan Alam yang bermanfaat dan dapat diterapkan dalam kehidupaaaan sehari-hari; 2) Mengembangkan rasa ingin tahu, sikap positif dan kesadaran tentang adanya hubungan yang saling mempengaruhi antar Ilmu Pengetahuan Alam, lingkungan tekhnologi dan masyarakat; 3) Mengembangkan keterampilan proses untuk menyelidiki alam sekitar, memecahkan masalah dan membuat keputusan; 4) Meningkatkan kesadaran untuk berperan serta dalam memelihara, menjaga, dan melestarikan lingkungan, 5) Menghargai alam dan segala keteraturannya sebagai salah satu ciptaan Allah SWT.

Ruang lingkup mata pelajaran ilmu pengetahuan alam di tingkat dasar meliputi dua aspek yaitu: 1) Kerja ilmiah yang mencakup: penyelidikan atau penelitian, berkomunikasi ilmiah, pengembangan kreatifitas dan pemecahan masalah, sikap dan nilai ilmiah; 2) Pemahaman konsep dan penerapannya yang mencakup: a) Makhluk hidup dan proses kehidupan, yaitu manusiaaa, hewan, tumbuhan dan interaksinya dengan lingkungan serta kesehatan; b) Benda dan materi, sifat-sifat dan kegunaannya meliputi cair, padaat dan gas; c) Energi dan perubahannya meliputi:gaya, bunyi, panas, magnet, listrik, cahaya dan pesawat sederhana; d) Bumi dan alam semesta meliputi: tanah, tata surya dan bendabenda langit lainnya; e) Pengetahuan alam dan saling keterkaitan dengan lingkungan, teknologi dan masyarakat melalui pembuata suatu karya teknologi sederhana termasuk merancang dan membuat. ${ }^{3}$

Pembelajaran Ilmu Pengetahuan Alam (IPA) di Sekolah Dasar (SD) adalah pondasi awal untuk mendidik siswa menjadi saintis yang sejati, hal ini dibutuhkan tuntutan bagi guru untuk memahami seutuhnya karakteristik anak SD tersebut. Usia anak SD berkisar antara 7 tahun sampai 12 tahun. Tahap

${ }^{7}$ Departemen Agama RI, Kurikulum Madrasah Ibtidayah (Standar Kompetensi). (Jakarta; Direktorat Jenderal Kelembagaan Agama Islam, 2004), h. 89.

Jurnal Ilmiah AL-MADRASAH, Vol. 3, No. 1, Juli-Desember 2018 
Mardiana: Penerapan Pembelajaran IPA Berbasis Konstruktivisme dalam Meningkatkan Sikap Ilmiah pada Siswa Madrasah Ibtidaiyah

perkembangan kognitif menjadi empat tahap, yaitu sensorimotorik (0-2 tahun), pra operasional (2-6/7 tahun), operasi konkret (6/7-11/12 tahun), dan operasi formal (11/12 tahun- dewasa). Siswa SD/MI berada pada tahap perkembangan operasi konkret, pada tahap ini telah menyadari pandangan orang lain dan juga bisa menggunakan lebih dari aspek untuk bahan pertimbangan. Oleh karena itu apabila diminta untuk mengelompokkan suatu objek mereka bisa menggunakan beberapa dasar pengelompokan. Pada tahap ini anak juga telah memahami permasalahan yang sifatnya konkrit.

Tujuan adalah landasan awal seorang guru untuk mengajar. Demikian juga dalam pembelajaran IPA, tujuan pada mata pelajaran IPA menjadi indikator keberhasilan pembelajaran. Pembelajaran tidak akan berhasil apabila seorang pendidik tidak mengetahui tujuan pembelajaran. Oleh sebab itu, hendaknya guru benar-benar memahami esensi dari tujuan pembelajaran. Tujuan pembelajaran IPA mencerminkan bagaimana tindakan-tindakan yang harus dilakukan agar keterampilan-keterampilan dan kecakapan-kecakapan yang diharapkan dapat dicapai pada diri siswa. ${ }^{8}$

IPA adalah usaha manusia dalam memahami alam semesta melalui pengamatan yang tepat pada sasaran, serta menggunakan prosedur, dan dijelaskan dengan penalaran sehingga mendapatkan suatu kesimpulan. Dalam hal ini para guru khususnya yang mengjar sains di SD diharapkan mengetahui dan mengerti hakikat pembelajaran IPA, sehingga dalam pembelajaran IPA guru tidak kesulitan dalam mendesain dan melasanakan pembelajaran. Siswa yang melakukan pembelajaran juga tidak mendapat kesulitan dalam memahami konsep sains. ${ }^{9}$

Hakikat pembelajaran sains yang didefinisikan sebagai ilmu tentang alam yang dalam bahasa indonesia disebut dengan Ilmu Pengetahuan Alam yang biasa disingkat dengan IPA. Pengertian hakikat IPA tersebut

\footnotetext{
${ }^{8}$ Tursinawati, Penerapan pembelajaran inkuiri terbimbing Untuk meningkatkan penguasaan konsep dan pemahaman hakikat sains siswa. (Bandung: UPI Press, 2008), h. 58.

${ }^{9}$ Widodo, Ari, dkk. Pendidikan IPA Di SD. (Bandung: UPI Press, 2007), h. 71.
}

Jurnal Ilmiah AL-MADRASAH, Vol. 3, No. 1, Juli-Desember 2018 
Mardiana: Penerapan Pembelajaran IPA Berbasis Konstruktivisme dalam Meningkatkan Sikap Ilmiah pada Siswa Madrasah Ibtidaiyah

diklasifikasikan menjadi tiga bagian yaitu IPA sebagai produk, IPA sebagai Proses, IPA sebagai Produk dan IPA sebagai sikap. ${ }^{10}$ Dari ketiga komponen ini, IPA juga sebagai prosedur dan IPA sebagai teknologi. akan tetapi penambahan ini bersifat pengembangan dari ketiga komponen di atas, yaitu pengembangan prosedur dari proses, sedangkan teknologi dari aplikasi konsep dan prinsipprinsip IPA sebagai produk. ${ }^{3}$ Sikap dalam pembelajaran IPA yang dimaksud ialah sikap ilmiah, jadi dengan pembelajaran IPA di sekolah dasar diharapkan dapat menumbuhkan sikap ilmiah seperti seorang ilmuwan. Adapun jenis-jenis sikap yang dimaksud adalah sikap ingin tahu, percaya diri, jujur, tidak tergesagesa dan objektif terhadap fakta. ${ }^{11}$

\section{Pembelajaran Berbasis Konstruktivisme}

Model pembelajaran konstruktivisme adalah salah satu pandangan tentang proses pembelajaran yang menyatakan bahwa dalam proses belajar (perolehan pengetahuan) diawali dengan terjadinya konflik kognitif. Konflik kognitif ini hanya dapat diatasi melalui pengetahuan akan dibangun sendiri oleh anak melalui pengalamannya dari hasil interaksi dengan lingkungannya. Konstruktivisme merupakan pandangan filsafat yang pertama kali dikemukakan oleh Giambatista Vico tahun 1710, ia adalah seorang sejarawan Italia yang mengungkapkan filsafatnya dengan berkata "Tuhan adalah pencipta alam semesta dan manusia adalah tuan dari ciptaan”. Dia menjelaskan bahwa "mengetahui" berarti "mengetahui bagaimana membuat sesuatu”. Ini berarti bahwa seseorang baru mengetahui sesuatu jika ia dapat menjelaskan unsur-unsur apa yang membangun sesuatu itu. ${ }^{12}$

Filsafat konstruktivisme beranggapan bahwa pengetahuan adalah hasil konstruksi manusia melalui interaksi dengan objek, fenomena pengalaman dan

\footnotetext{
${ }^{10}$ Holbrook, Jack dan Rannikmae, Miia. The Nature of Science Education for Enhancing Scientific Literacy. (Intenational Jurnal of Science Education, 2007) h. 1347-1362.

${ }^{11}$ Silberman, Mel. Active Learning Second Edition. (New Jersey: A Willey Company, 1998), h. 315.

${ }^{12}$ Suparno, Paul. Filsafat Konstruktivisme dalam Pendidikan. (Jogjakarta: Kanisius, 1997), h. 123.
}

Jurnal Ilmiah AL-MADRASAH, Vol. 3, No. 1, Juli-Desember 2018 
Mardiana: Penerapan Pembelajaran IPA Berbasis Konstruktivisme dalam Meningkatkan Sikap Ilmiah pada Siswa Madrasah Ibtidaiyah

lingkungan mereka. Konstruktivisme bertitik tolak dari pembentukan pengetahuan, dan rekonstruksi pengetahuan adalah mengubah pengetahuan yang dimiliki seseorang yang telah dibangun atau dikonstruk sebelumnya dan perubahan itu sebagai akibat dari interaksi dengan lingkungannya. ${ }^{13}$

Konstruktivisme adalah salah satu pandangan tentang proses pembelajaran yang menyatakan bahwa dalam proses belajar (perolehan pengetahuan) diawali dengan terjadinya konflik kognitif yang hanya dapat diatasi melalui pengetahuan diri dan pada akhir proses belajar pengetahuan akan dibangun oleh anak melalui pengalamannya dari hasil interkasi dengan lingkungannya. Konflik kognitif tersebut terjadi saat interaksi antara konsepsi awal yang telah dimiliki siswa dengan fenomena baru yang dapat diintegrasikan begitu saja, sehingga diperlukan perubahan/modifikasi struktur kognitif untuk mencapai keseimbangan, peristiwa ini akan terjadi secara berkelanjutan, selama siswa menerima pengetahuan baru. ${ }^{10}$

Berdasarkan pandangan tersebut, dapat disimpulkan bahwa model konstruktivisme dalam pembelajaran adalah suatu proses belajar mengajar dimana siswa sendiri aktif secara mental, membangun pengetahuannya, yang dilandasi oleh struktur kognitif yang dimilikinya. Guru lebih berperan sebagai fasilitator dan mediator pembelajaran. Penekanan tentang belajar dan mengajar lebih berfokus terhadap suksesnya siswa mengorganisasi pengalaman mereka.seorang guru tidak mengajarkan kepada anak bagaimana menyelesaikan persoalan, namun mempresentasikan masalah dan mendorong siswa untuk menemukan cara mereka sendiri dalam menyelesaikan permasalahan. Ketika siswa memberikan jawaban, guru mencoba untuk tidak mengatakan bahwa jawabannya benar atau tidak benar. Namun guru mendorong siswa untuk setuju

\footnotetext{
${ }^{13}$ Surya, Pembelajaran berbasis konstruktivisme pada sekolah tingkat Dasar. ( Bandung: Jurnal Sains Universitas Pendidikan Indonesia, 2011), h. 3.
}

Jurnal Ilmiah AL-MADRASAH, Vol. 3, No. 1, Juli-Desember 2018 
Mardiana: Penerapan Pembelajaran IPA Berbasis Konstruktivisme dalam Meningkatkan Sikap Ilmiah pada Siswa Madrasah Ibtidaiyah

atau tidak setuju kepada ide seseorang dan saling tukar menukar ide sampai persetujuan dicapai tentang apa yang dapat masuk akal siswa. ${ }^{14}$

Menurut faham konstruktivis pengetahuan merupakan konstruksi (bentukan) dari orang yang mengenal sesuatu (skemata). Pengetahuan tidak bisa ditransfer dari guru kepada orang lain, karena setiap orang mempunyai skema sendiri tentang apa yang diketahuinya. Pembentukan pengetahuan merupakan proses kognitif di mana terjadi proses asimilasi dan akomodasi untuk mencapai suatu keseimbangan sehingga terbentuk suatu skema (jamak: skemata) yang baru. Seseorang yang belajar itu berarti membentuk pengertian atau pengetahuan secara aktif dan terus-menerus. ${ }^{10}$

Bagi konstruktivisme, kegiatan belajar adalah kegiatan yang aktif, di mana peserta didik membangun sendiri pengetahuan, keterampilan dan tingkah lakunya. Peserta didik mencari arti sendiri dari yang mereka pelajari. Peserta didik sendiri lah yang bertanggung jawab terhadap hasil belajarnya. Mereka sendiri yang membuat penalaran dengan apa yang dipelajarinya, dengan cara mencari makna, membandingkan dengan apa yang telah ia ketahui dengan pengalaman dan situasi baru.Ciri-ciri Pembelajaran Konstruktivisme adalah sebagai berikut.

a. menyediakan pengalaman belajar dengan mengkaitkan pengetahuan yang telah dimiliki siswa sedemikian rupa sehingga belajar melalui proses pembentukan pengetahuan,

b. menyediakan berbagai alternatif pengalaman belajar, tidak semua mengerjakan tugas yang sama, misalnya suatu masalah dapat diselesaikan dengan berbagai cara,

c. mengintegrasikan pembelajaran dengan situasi yang realistik dan relevan dengan melibatkan pengalaman konkrit, misalnya untuk memahami suatu konsep melalui kenyataan kehidupan sehari-hari,

\footnotetext{
${ }^{14}$ Trianto. Model-model Pembelajaran Inovatif Berorientasi Konstruktivistik. (Jakarta: Prestasi Pustaka, 2011), h. 165.
}

Jurnal Ilmiah AL-MADRASAH, Vol. 3, No. 1, Juli-Desember 2018 
Mardiana: Penerapan Pembelajaran IPA Berbasis Konstruktivisme dalam Meningkatkan Sikap Ilmiah pada Siswa Madrasah Ibtidaiyah

d. mengintegrasikan pembelajaran sehingga memungkinkan terjadinya transmisi sosial yaitu terjadinya interaksi dan kerja sama seseorang dengan orang lain atau dengan lingkungannya, misalnya interaksi dan kerjasama antara siswa, guru, dan siswa-siswa,

e. memanfaatkan berbagai media termasuk komunikasi lisan dan tertulis sehingga pembelajaran menjadi lebih efektif.

f. Melibatkan siswa secara emosional dan sosial sehingga menjadi menarik dan siswa mau belajar. ${ }^{12}$

\section{Pembelajaran IPA berbasis Konstruktivisme}

Konstruktivisme adalah satu prinsip paling penting dari psikologi pendidikan adalah guru tidak hanya semata-mata memberikan pengetahuan kepada siswa. Siswa harus membangun pengetahuan di dalam benaknya sendiri. Guru dapat membantu proses ini dengan memberikan kesempatan kepada siswa untuk menemukan dan menerapkan ide-ide mereka untuk belajar. Paradigma konstruktivisme memandang siswa sebagai pribadi yang sudah memiliki kemampuan awal sebelum mempelajari sesuatu. Kemampuan awal tersebut akan menjadi dasar dalam mengkonstruksi pengetahuan yang baru. ${ }^{15}$

Pendekatan konstruktivisme menghendakai siswa harus membangun pengetahuan di dalam benaknya sendiri. Guru dapat membantu proses ini dengan cara mengajar yang membuat informasi lebih bermakna dengan memberikan kesempatan kepada siswa untuk menemukan atau menerapkan sendiri ide-ide mereka. Guru dapat memberi siswa tangga yang dapat membantu siswa mencapai tingkat pemahaman yang lebih tinggi, namun harus diupayakan agar siswa sendiri yang memanjat tangga tersebut. Oleh karena itu agar pembelajaran lebih bermakna bagi siswa dan pendidik maka pendekatan konstruktivisme merupakan solusi yang baik untuk dapat diterapkan. Berikut

${ }^{15}$ Budiningsih, C.A. Belajar dan Pembelajaran. (Jakarta: Rineka Cipta, 2005), h. 32.

Jurnal Ilmiah AL-MADRASAH, Vol. 3, No. 1, Juli-Desember 2018 
Mardiana: Penerapan Pembelajaran IPA Berbasis Konstruktivisme dalam Meningkatkan Sikap Ilmiah pada Siswa Madrasah Ibtidaiyah

akan dipaparkan perbedaan pembelajaran tradisional (behavioristik) dengan pembelajaran yang konstruktivistik. ${ }^{16}$

Proses belajar mengajar diperlukan suatu cara atau metode untuk mencapai tujuan belajar. Metode mengajar adalah suatu cara, teknik atau langkah-langkah yang akan ditempuh dalam proses belajar mengajar. ${ }^{17}$ Metode mengajar adalah teknik penyajian yang dikuasai guru untuk mengajar atau menyajikan bahan pelajaran kepada siswa di dalam kelas agar pelajaran tersebut dapat ditangkap, dipahami dan digunakan oleh siswa dengan baik. ${ }^{18}$

Ada berbagai metode berbasis kontruktivisme yang dapat digunakan guru dalam kegiatan pembelajaran, diantaranya; ceramah bervariasi, tanya jawab, diskusi, pemberian tugas, bermain peran, karyawisata, inquiry, kerja kelompok, discovery, demonstrasi. Karena keterbatasan kemampuan dan waktu maka tidak akan semua metode dapat digunakan. Namun yang terpenting adalah penggunaan metode harus dikaitkan dengan situasi dan tujuan belajar yang hendak dicapai dan ditekankan kepada keaktifan siswa dalam membangun pengetahuan. $^{12}$

Hal-hal penting yang harus dilakukan seorang guru konstruktivis sebagai berikut.

a. Guru perlu mendengarkan secara sungguh-sungguh interpretasi murid terhadap data yang ditemukan sambil menaruh perhatian khusus kepada keraguan, kesulitan dan kebingungan setiap murid.

b. Guru perlu memperhatikan perbedaan pendapat dalam kelas dan juga memberikan penghargaan kepada siswa.

c. Guru perlu menyadari bahwa ketidaktahuan siswa bukanlah suatu hal yang jelek dalam proses belajar, karena "tidak mengerti” merupakan langkah awal untuk memulai. ${ }^{10}$

\footnotetext{
${ }^{16}$ Matthew H. Theories Of Learning, Edisi Ketujuh. (Jakarta: Kencana, 2008), h. 97

${ }^{17}$ Abidin, Y. Desain Sistem Pembelajaran Dalam Konteks Kurikulum 2013. (Bandung: PT Refika Adikarya, 2014), h. 214.

${ }^{18}$ Tri Anni, Catharina. Psikologi Belajar. (Semarang: UPT MKK UNNES, 2004), h. 45.
} 
Mardiana: Penerapan Pembelajaran IPA Berbasis Konstruktivisme dalam Meningkatkan Sikap Ilmiah pada Siswa Madrasah Ibtidaiyah

Peran guru dalam pembelajaran konstruktivis sangat menuntut penguasaan bahan yang luas dan mendalam tentang bahan yang diajarkan. Pengetahuan yang luas dan mendalam memungkinkan seorang guru menerima pandangan dan gagasan yang berbeda dari murid dan juga memungkinkan untuk menunjukkan apakah gagasan itu jalan atau tidak. Penguasaan bahan memungkinkan seorang guru mengerti macam-macam jalan dan model untuk sampai pada suatu pemecahan persoalan tanpa terpaku pada satu model

4. Sikap Ilmiah pada pembelajaran IPA

Makna "sikap" pada pengajaran IPA SD/MI dibatasi pengertiannya pada sikap ilmiah terhadap perolehan ilmu pengetahuan alam sekitar, setidaktidaknya ada sembilan aspek sikap dari sikap ilmiah yang dapat dikembangkan pada anak usia SD/MI, yaitu: Sikap ingin tahu, sikap ingin mendapat sesuatu yang baru, sikap tidak putus asa, sikap tidak berprasangka, sikap mawas diri, sikap bertanggung jawab, sikap berpikir bebas, sikap kedisiplinan diri. ${ }^{19}$

Seorang guru sains dituntut untuk mempunyai gambaran yang jelas dan tepat tentang apa itu sains, sebab keyakinan tentang sains akan sangat berpengaruh terhadap bagaimana seorang guru mengajarkan sains. Sains membutuhkan pembelajaran konsep ilmiah dan mengembangkan kemampuan berpikir ilmiah. Ruang kelas yang efektif bergantung pada berbagai cara mengajar ilmu tersebut. Apabila proses pengamatan dan pertanyaan muncul, memberikan kesempatan untuk berinteraksi lebih dengan fenomena dan lebih besar potensi untuk pengembangan pemahaman lebih lanjut. ${ }^{7}$

\section{Hasil dan Pembahasan}

Pembelajaran IPA berbasis konstruktivisme merupakan hal yang sangat penting untuk diterapkan untuk mencapai tujuan pembelajaran yang diharapkan. pembelajaran IPA berbasis konstruktivisme yang secara langsung dapat

\footnotetext{
${ }^{19}$ Sulistyorini, Pembelajaran IPA Sekolah Dasar Dan Penerapan Dalam KTSP. (Yogyakarta: Unnes dan Tiara Wacana, 2007), h. 117.
}

Jurnal Ilmiah AL-MADRASAH, Vol. 3, No. 1, Juli-Desember 2018 
Mardiana: Penerapan Pembelajaran IPA Berbasis Konstruktivisme dalam Meningkatkan Sikap Ilmiah pada Siswa Madrasah Ibtidaiyah

membuat siswa secara aktif mengkonstruksi pengetahuan sendiri, sehingga dapat mengembangkan kemampuan berpikir siswa, meningkatkan penguasaan materi pembelajaran dan dapat menumbuhkan sikap ilmiah yang secara tidak langsung akan mempengaruhi sikap siswa dalam memecahkan masalah yang ada di lingkungan sekitar. Sikap ilmiah sangat bermakna dalam interaksi sosial, ilmu pengatahuan dan teknologi. Apabila sikap ilmiah telah terbentuk dalam diri siswa maka akan terwujudlah suri tauladan yang baik bagi peserta didik, baik dalam melaksanakan penyelidikan atau berinteraksi dengan masyarakat. Secara tidak langsung sikap ilmiah dalam proses pembelajaran IPA dapat menyelesaikan masalah-masalah moralitas anak bangsa ini.

Hal ini sesuai dengan Rekapitulasi Secara Keseluruhan Hasil Sikap Ilmiah Siklus I dan II pada tabel 1. Berikut.

\begin{tabular}{ccc}
\hline $\begin{array}{c}\text { Jumlah } \\
\text { Siswa }\end{array}$ & Siklus & $\begin{array}{c}\text { Persentase } \\
\text { Pencapaian Klasikal } \\
(\%)\end{array}$ \\
\hline \multirow{2}{*}{35} & I & 84,5 \\
& II & 91,2 \\
\hline
\end{tabular}

Berdasarkan Tabel 1. dapat dibuat grafik peningkatan hasil sikap ilmiah siswa berikut pada Gambar 1 .

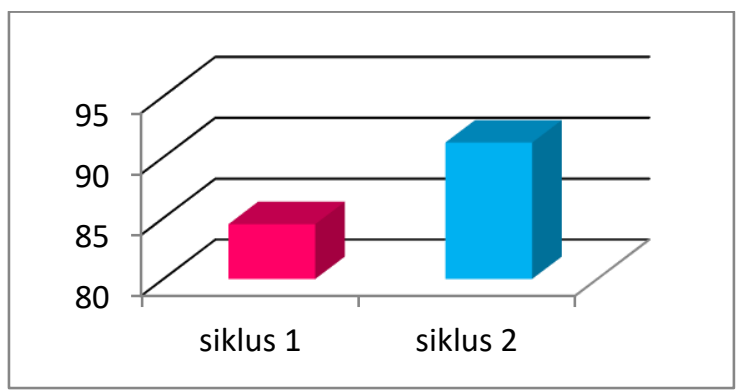

Berdasarkan hasil temuan penelitian yang telah dianalisis, menunjukkan hasil yang sangat baik dan terjadi peningkatan hasil belajar dari siklus I ke siklus II. Hal tersebut terlihat dari kedua Siklus yang menunjukan dengan nilai 
Mardiana: Penerapan Pembelajaran IPA Berbasis Konstruktivisme dalam Meningkatkan Sikap Ilmiah pada Siswa Madrasah Ibtidaiyah

yang baik dan peningkatan dengan rata-rata nilai di siklus I sebesar 84,5\% dan di siklus II sebesar 91,2\%. Hal tersebut membuktikan terjadi peningkatan sikap ilmiah sebesar 7,7 \%. Berdasarkan hasil penelitian yang telah dipaparkan diatas dapat ditarik kesimpulan bahwaa Proses pembelajaran akan berhasil dengan baik apabila guru membuat perencanaan dengan mempertimbangkan aspek siswa, materi, urutan sajian materi, rangkaian proses berfikir siswa dan keterampilan siswa, alat peraga dan penilaian. Perencanaan yang dibuat guru bertujuan untuk memberi kemudahan kepada siswa dalam memberikan rangsangan bimbingan, pengarahan dan memberikan dorongan belajar sebaliknya lebih banyak dilakukan oleh siwa (siswa lebih aktif) melalui berbagai kegiatan : mengalami, melakukan, mencari dan menemukan sendiri konsep yang dipelajarinya.

Proses pembelajaran banyak segi yang seharusnya dicapai sebagai hasil belajar, yang meliputi pengetahuan dan pengalaman tentang konsep, kemampuan menerapkan konsep, kemampuan menarik kesimpulan serta menilai kesimpulan serta menilai kemanfaatan suatu konsep, menyenangi dan merespon positif terhadap mata pelajaran IPA. Sebagai upaya untuk memperbaiki citra pelajaran IPA, maka guru perlu membaharui gaya mengajarnya. Pendekatan yang dipilih dan digunakan guru hendaknya merupakan pendekatan mengajar yang dapat mengarahkan dan membimbing siswa senang terhadap pelajaran IPA. Sehingga anggapan IPA sebagai pelajaran yang membosankan dapat berubah menjadi pelajaran yang menarik dan menyenangkan. Salah satu pendekatan mengajar yang dapat menarik minat siswa untuk belajar adalah pendekatan konstruktivisme. Melalui pendekatan konstruktivisme, siswa diajak untuk memasuki dunia IPA dengan cara yang menyenangkan. Dimana siswa dapat beraktifitas dan terlibat secara penuh dalam memperoleh pengetahuannya.

Berdasarkan pandangan tersebut, dapat disimpulkan bahwa model konstruktivisme dalam pembelajaran adalah suatu proses belajar mengajar dimana siswa sendiri aktif secara mental, membangun pengetahuannya, yang

Jurnal Ilmiah AL-MADRASAH, Vol. 3, No. 1, Juli-Desember 2018 
Mardiana: Penerapan Pembelajaran IPA Berbasis Konstruktivisme dalam Meningkatkan Sikap Ilmiah pada Siswa Madrasah Ibtidaiyah

dilandasi oleh struktur kognitif yang dimilikinya. Guru lebih berperan sebagai fasilitator dan mediator pembelajaran. Penekanan tentang belajar dan mengajar lebih berfokus terhadap suksesnya siswa mengorganisasi pengalaman mereka.

Kelas konstruktivis seorang guru tidak mengajarkan kepada anak bagaimana menyelesaikan persoalan, namun mempresentasikan masalah dan mendorong siswa untuk menemukan cara mereka sendiri dalam menyelesaikan permasalahan. Ketika siswa memberikan jawaban, guru mencoba untuk tidak mengatakan bahwa jawabannya benar atau tidak benar. Namun guru mendorong siswa untuk setuju atau tidak setuju kepada ide seseorang dan saling tukar menukar ide sampai persetujuan dicapai tentang apa yang dapat masuk akal siswa.

Bagi konstruktivisme, kegiatan belajar adalah kegiatan yang aktif, di mana peserta didik membangun sendiri pengetahuan, keterampilan dan tingkah lakunya. Peserta didik mencari arti sendiri dari yang mereka pelajari. Peserta didik sendiri lah yang bertanggung jawab terhadap hasil belajarnya. Mereka sendiri yang membuat penalaran dengan apa yang dipelajarinya, dengan cara mencari makna, membandingkan dengan apa yang telah ia ketahui dengan pengalaman dan situasi baru.

Hal tersebut bisa dilakukan dengan pembelajaran IPA berbasis konstruktivisme yang secara langsung dapat membuat siswa secara aktif mengkonstruksi pengetahuan sendiri, sehingga dapat mengembangkan kemampuan berpikir siswa, meningkatkan penguasaan materi pembelajaran dan dapat menumbuhkan sikap ilmiah yang secara tidak langsung akan mempengaruhi sikap siswa dalam memecahkan masalah yang ada di lingkungan sekitar. Sikap ilmiah sangat bermakna dalam interaksi sosial, ilmu pengatahuan dan teknologi. Apabila sikap ilmiah telah terbentuk dalam diri siswa maka akan terwujudlah suri tauladan yang baik bagi peserta didik, baik dalam melaksanakan penyelidikan atau berinteraksi dengan masyarakat.

Jurnal Ilmiah AL-MADRASAH, Vol. 3, No. 1, Juli-Desember 2018 
Mardiana: Penerapan Pembelajaran IPA Berbasis Konstruktivisme dalam Meningkatkan Sikap Ilmiah pada Siswa Madrasah Ibtidaiyah

\section{E. Penutup}

a. Simpulan

Penerapan pembelajaran IPA berbasis Konstruktivisme dapat meningkatkan sikap ilmiah pada siswa madrasah ibtidayah. Pembelajaran IPA berbasis konstruktivisme yang secara langsung dapat membuat siswa secara aktif mengkonstruksi pengetahuan sendiri, sehingga dapat mengembangkan kemampuan berpikir siswa, meningkatkan penguasaan materi pembelajaran dan dapat menumbuhkan sikap ilmiah yang secara tidak langsung akan mempengaruhi sikap siswa dalam memecahkan masalah yang ada di lingkungan sekitar serta penekanan tentang belajar dan mengajar lebih berfokus terhadap suksesnya siswa mengorganisasi pengalaman mereka sehinggan akan terbentuk sikap ilmiah secara alami.

Sikap ilmiah sangat bermakna dalam interaksi sosial, ilmu pengatahuan dan teknologi. Apabila sikap ilmiah telah terbentuk dalam diri siswa maka akan terwujudlah suri tauladan yang baik bagi peserta didik, baik dalam melaksanakan penyelidikan atau berinteraksi dengan masyarakat. Secara tidak langsung sikap ilmiah dalam proses pembelajaran IPA dapat menyelesaikan masalah-masalah moralitas anak bangsa ini.

b. Saran

Guru perlu membiasakan proses pembelajaran ipa berbasis konstruktivisme untuk mengembangkan kemampuan siswa dalam menemukan pengetahuan baru, memahami isi pelajaran serta sikap ilmiah siswa. Pada kelas konstruktivisme seorang guru tidak mengajarkan kepada anak bagaimana menyelesaikan persoalan, namun mempresentasikan masalah dan mendorong siswa untuk menemukan cara mereka sendiri dalam menyelesaikan permasalahan. Ketika siswa memberikan jawaban, guru mencoba untuk tidak mengatakan bahwa jawabannya benar atau tidak benar. Namun guru mendorong siswa untuk setuju atau tidak setuju kepada ide seseorang dan saling tukar 
Mardiana: Penerapan Pembelajaran IPA Berbasis Konstruktivisme dalam Meningkatkan Sikap Ilmiah pada Siswa Madrasah Ibtidaiyah

menukar ide sampai persetujuan dicapai tentang apa yang dapat masuk akal siswa.

Guru lebih berperan sebagai fasilitator dan mediator pembelajaran. Guru hendaknya melakukan pendekatan mengajar yang dapat mengarahkan dan membimbing siswa senang terhadap pelajaran. Penekanan tentang belajar dan mengajar lebih berfokus terhadap suksesnya siswa mengorganisasi pengalaman mereka.

Berdasarkan pemaparan tersebut sangat diharapkan seorang guru dapat menerapkan suatu pendekatan, model pembelajaran, metode dan strategi dalam proses belajar mengajar karena dapat membantu siswa dalam meningkatkan pengetahuan, sikap dan keterampilan secara baik dan menyeluruh. Oleh karena itu, seorang guru diharapkan memiliki pengetahuan yang luas tentang strategi belajar mengajar yang baik.

Jurnal Ilmiah AL-MADRASAH, Vol. 3, No. 1, Juli-Desember 2018 
Mardiana: Penerapan Pembelajaran IPA Berbasis Konstruktivisme dalam Meningkatkan

Sikap Ilmiah pada Siswa Madrasah Ibtidaiyah

\section{Daftar Pustaka}

Abidin, Y. Desain Sistem Pembelajaran Dalam Konteks Kurikulum 2013. Bandung: PT Refika Adikarya, 2014.

Budiningsih, C.A. Belajar dan Pembelajaran. Jakarta : Rineka Cipta, 2005.

Chain \& Evan, Sciencing An Involvement Approach to Elementary Science Methods, (Edisi ke III. Korinna: Merrill,1990).

Darmiwati. Implementasi Model Pembelajaran Perubahan Konseptual Untuk Meningkatkan Prestasi Belajar. Banda Aceh: FKIP Unsyiah, 2006.

Departemen Agama RI, KurikulumMadrasah Ibtidayah (Standar Kompetensi), Jakarta; Direktorat Jenderal Kelembagaan Agama Islam,2004

Holbrook, Jack dan Rannikmae, Miia. The Nature of Science Education for Enhancing Scientific Literacy. Intenational Jurnal of Science Education Vol 29, No 11, 3 September 2007, PP. 1347-1362, 2007.

Husin dan Bahrul Ilmi, " Strategi Cooverative Learning dalam Perspektif Pendidikan Islam", Al-Madrasah Vol. 3, No. 1 (2018).

Matthew H.Theories Of Learning, Edisi Ketujuh. Jakarta: Kencana, 2008.

S Hornby,A. Oxford Advanced Learner`sDictionary Of Current English. Ne York: Oxford University Pres, 2010

Sardiman A. M. Interaksi dan Motivasi Belajar Mengajar. Jakarta: PT. Raja Grafindo Persada, 2007.

Silberman, Mel. Active Learning (Second Edition). New Jersey: A Willey Company, 1998.

Sulistyorini, Sri. Pembelajaran IPA Sekolah Dasar, Dan Penerapan Dalam KTSP. Yogyakarta: Unnes dan Tiara Wacana, 2007.

Suparno, Paul. Filsafat Konstruktivisme dalam Pendidikan. Jogjakarta: Kanisius, 1997.

Surya, Pembelajaran berbasis konstruktivisme pada sekolah tingkat Dasar. Jurnal Sains. Universitas Pendidikan: Bandung, Vol. 6 no 3 (2011)

Tri Anni, Catharina. Psikologi Belajar. Semarang: UPT MKK UNNES, 2004.

Trianto. Model-model Pembelajaran Inovatif Berorientasi Konstruktivistik. Jakarta: Prestasi Pustaka, 2011.

Tursinawati. Penerapan pembelajaran inkuiri terbimbing Untuk meningkatkan penguasaan konsep dan pemahaman hakikat sains siswa. Bandung: UPI Press. (Tesis, tidak diterbitkan), 2008.

Jurnal Ilmiah AL-MADRASAH, Vol. 3, No. 1, Juli-Desember 2018 
Mardiana: Penerapan Pembelajaran IPA Berbasis Konstruktivisme dalam Meningkatkan Sikap Ilmiah pada Siswa Madrasah Ibtidaiyah

Undang-undang Republik Indonesia No 20 pasal Tentang Sistem Pendidikan Nasional. Jakarta: CV Multi Persindo. 2013

Widodo, Ari, dkk. Pendidikan IPA Di SD. Bandung: UPI Press, 2007. 
Mardiana: Penerapan Pembelajaran IPA Berbasis Konstruktivisme dalam Meningkatkan Sikap Ilmiah pada Siswa Madrasah Ibtidaiyah

Jurnal Ilmiah AL-MADRASAH, Vol. 3, No. 1, Juli-Desember 2018 